\title{
Prevalence of Protozoa in Gastrointestinal Tract of Pigeons (Columba livia) Maintenance Ekstensif and Intensif in Surabaya
}

\section{Prevalensi Protozoa Saluran Cerna Burung Merpati (Columba livia) pada Pemeliharaan Ekstensif dan Intensif di Surabaya}

\author{
${ }^{1)}$ Felita Widyaningsih, ${ }^{2)}$ Muchammad Yunus, ${ }^{3}$ Rimayanti, ${ }^{2)}$ Setiawan Koesdarto, ${ }^{2)}$ Lucia Tri \\ Suwanti, ${ }^{2)}$ Agus Sunarso \\ ${ }^{1)}$ Student, ${ }^{2)}$ Department of Veterinary Parasitology, ${ }^{3)}$ Department of Veterinary Reproduction. Faculty of \\ Veterinary Medicine, Airlangga University.
}

\begin{abstract}
This research was conducted to determine the prevalence of major gastrointestinal protozoal infections, the kinds of protozoa that infects and maintenance systems influence on pigeons in Surabaya. Pigeon taken from five regions of Surabaya namely North Surabaya, East Surabaya, West Surabaya, South Surabaya and Surabaya Center. Each region is taken as many as 20 pigeons consisted of 10 pigeons with extensive maintenance system and 10 pigeons with intensif maintenance system. So that the total overall sample is 100 pigeons. Laboratory examination (microscopic) was conducted in November 2017 until January 2017. Examination of the upper gastrointestinal tract using throat swabs and stool samples were examined with native methods, sedimentation, and flotation. Identification using a microscope using 40x objective scale and 1ox oculer scale to determine gastrointestinal protozoal that was found. Data was analyzed using Chi Square Test statistical analysis. Results showed $78 \%$ of the positive samples gastrointestinal protozoa infections in pigeons in the city of Surabaya. Results of Chi Square Test statistical analysis showed a p value of $0.030(\mathrm{p}<0.05)$ which means significantly different. Types of protozoa found that Trichomonas gallinae (49\%) and Eimeria sp. (61\%). The prevalence of gastrointestinal protozoal pigeons on extensive maintenance sistem was higher (44\%) compared to the intensive caresis system(34\%).
\end{abstract}

Keywords: Prevalence, protozoa gastrointestinal tract, pigeons, Trichomonas gallinae

\section{Pendahuluan}

Burung Merpati atau Columba livia yang dikenal sebutan burung dara adalah salah satu spesies pada famili Columbidae dan merupakan salah satu kekayaan fauna Indonesia yang memiliki keragaman tinggi (Hamid dkk, 2015). Kegiatan usaha beternak merpati diminati masyarakat Indonesia karena produktifitas perkembangbiakan yang cepat.

Sistem pemeliharan merpati di Indonesia antara lain sistem pemeliharaan ekstensif yaitu sistem pemeliharaan merpati dengan menggunakan kandang sederhana yang diletakkan di depan rumah ataupun di atap rumah. Sistem pemeliharaan ekstensif ini sering digunakan masyarakat dan biasa disebut dengan pegupon.
Pemberian pakan yang dilakukan diluar kandang berupa padi, sisa nasi yang kering, dedak padi atau jagung, dan untuk memenuhi nutrisi lainnya merpati akan mencari sendiri disekitarnya. Kedua dengan pemeliharaan intensif yaitu pemeliharaan dengan cara tertutup yang menempatkan merpati dalam kandang, segala kebutuhan pakan, minum, dan nutrisi disediakan seluruhnya oleh pemilik atau peternak (Hamid dkk, 2015).

Manajemen pemeliharaan yang minimalis akan mengakibatkan sistem kekebalan tubuh menurun sehingga peka terhadap penyakit. Selain sistem pemeliharaan yang kurang baik, faktor lain yang dapat menyebabkan merpati mudah terinfeksi penyakit diantaranya bakteri, virus, parasit dan jamur yang dibawa oleh hewan 
lain, kontak dengan inang antara, dan kontaminasi agen penyakit melalui pakan (Dove et al., 2004).

Parasit dapat menimbulkan berbagai masalah, gejala dan menyebabkan kerugian yang sangat besar pada peternakan burung merpati antara lain terhambatnya pertumbuhan burung, produktifitas telur yang menurun, dan tingkat kerentanan pada penyakit lain yang lebih tinggi (Dranzoa et al, 1999). Infeksi parasit dapat mengakibatkan perubahan perilaku pada induk semang definitif, antara lain penurunan potensi terbang pada burung dan dapat mengganggu proses produksi serta reproduksinya (Saumier et al., 1991).

Pemberian pakan, kondisi kandang dan sanitasi yang kurang baik menyebabkan merpati mudah terserang penyakit. Akibat kondisi tersebut, penyakit parasit muncul terlebih dulu dari penyakit lain (Adejinmi and Oke, 2011). Lingkungan yang lembab dan kotor merupakan tempat perkembangan beberapa agen penyakit parasit, salah satunya adalah penyakit yang disebabkan oleh protozoa. Peternakan burung merpati mendapatkan kerugian ekonomi yang sangat besar akibat keberadaan salah satu jenis protozoa yaitu protozoa saluran cerna. Kasus infeksi yang tidak ditangani menyebabkan tingkat mortalitas yang tinggi, serta tingkat morbiditas yang signifikan meningkat (Samour et $a l$, 1995). Menurut keterangan Taylor et al., pada tahun 2007 menyebutkan bahwa protozoa yang ada pada saluran cerna burung merpati terdiri dari famili Eiimeriidae, Trichomonadidae, Monocercomonadidae, dan Diplomonadidae.

Berdasarkan kegunaan burung merpati yang banyak diminati masyarakat Surabaya, maka perlu dilakukan penelitian terhadap prevalensi protozoa pada saluran cerna burung merpati di lima wilayah Surabaya yaitu Surabaya Utara, Surabaya Timur, Surabaya Selatan, Surabaya Barat, dan Surabaya Pusat. Serta melihat perbedaan antar sistem pemeliharaan ekstensif dan intensif terhadap tingkat infeksi. .Jika telah diketahui data tentang tingkat kejadian protozoa saluran cerna khususnya di Surabaya dapat bermanfaat dalam usaha pencegahan terhadap penyakit protozoa saluran cerna pada burung merpati.

\section{Metode Penelitian}

Penelitian telah dilakukan pada bulan November 2016 hingga Januari 2017 di Departemen Parasitologi Veteriner Kedokteran Hewan Universitas Airlangga.

Sampel yang digunakan dalam penelitian ini adalah 100 ekor burung merpati yang diambil dari lima wilayah Surabaya yaitu Surabaya Utara, Surabaya Timur, Surabaya Selatan, Surabaya Barat, dan Surabaya Pusat. Masing - masing wilayah diambil 20 sampel (1o sampel peternakan ekstensif dan 10 peternakan intensif)

Bahan yang digunakan dalam penelitian antara kalium bikromat 2,5\%, larutan gula jenuh, aquades, $\mathrm{NaCl}$. Alat yang digunakan yaitu pot sampel, saringan, gelas plastik, tabung sentrifus, stiker tabel, hand glove, pipet, gelas obyek, gelas penutup, sentrifus, mikroskop, catton bud, cawan petri.

\section{Metode Pemeriksaan Swab Kerongkongan Burung Merpati}

Pemeriksaan dilakukan pada burung merpati yang diduga memiliki gejala klinis dari Trichomoniasis (Begum et al., 2008). Pemeriksaan swab kerongkongan dilakukan pada bagian mulut dan kerongkongan dengan membuka paruh burung merpati yang selanjutnya dimasukkan dan digerakkan secara memutar catton bud yang telah dibasahi dengan $\mathrm{NaCl}$ fisiologis. Hasil swab tersebut segera diletakkan pada gelas obyek dan ditutp dengan gelas penutp untuk dilakukan pemeriksaan mikroskop. Setelah sampel positif dilakukan pewarnaan menggunakan larutan Giemsa 10 \% (5 ml Giemsa dan $45 \mathrm{ml}$ aquades). Hasil swab pada gelas obyek dibiarkan mengering lalu difiksasi dengan methanol 1-2 menit. Kemudian direndam dengan larutan Giemsa 10\% pada coplain jar selama 10-15 menit. mencuci hasil perendaman dengan air mengalir, dibiarkan kering, dan dilakukan pemeriksaan mikroskop (Prasetyo, 2005).

\section{Pemeriksaan Feses Burung Merpati Metode Natif}

Pengambilan feses dilakukan dengan menggunakan ujung lidi, kemudian dioleskan pada gelas obyek. Menambahkan satu sampai dua tetes air, kemudian meratakan dan menutup dengan gelas penutup. Melalui pemeriksaan 
mikroskop dengan perbesaran 40ox (Natadisastra dan Agoes, 2009).

\section{Metode Sedimen}

Feses dibuat suspensi dengan penambahan aquades dan disaring. Lurutan tersebut dimasukkan tabung sentrifus dan disentrifus selama lima menit dengan kecepatan 1500 rpm. Supernatan dibuang dan ditambahkan aquades lalu disentrifus. Pengulangan hal tersebut hingga supernatant nampak jernih. Supernatan jernih dibuang dan disisakan endapan. Endapan tersebut diadus dan diteteskan pada gelas obyek lalu ditutup dengan gelas penutup untuk dilakukan pemeriksaan mikroskop (Suwanti dkk, 2010)

\section{Metode Pengapungan}

Suspensi feses dan air hingga terbentuk filtrat. Mengisi abung sentrifus dengan filtrate hingga ketinggian $2 \mathrm{~cm}$ diatas mulut tabung, disentrifus dengan kecepatan 1500 rpm selama lima menit. Dilakukan hingga supernatan nampak jernih. Supernatant yang jernih dibuang dan diganti dengan larutan gula jenuh untuk disentrifus dengan kecepatan dan waktu yang sama. Penambahan gula jenuh hingga terlihat cembung pada mulut tabung. Menutup mulut tabung dengan gelas penutup dan mendiamkan selama lima menit untuk selanjutnya diperiksa dengan mikroskop (Sucitrayani dkk, 2012).

\section{Hasil Penelitian dan Pembahasan}

Pemeriksaan swab kerongkongan dan feses pada 100 ekor burung merpati lima wilayah Surabaya menunjukkan prevalensi sebesar 78 ekor $(78 \%)$ posititif terinfeksi protozoa saluran cerna. Infeksi tersebut terdiri dari infeksi campuran Trichomonas gallinae dan Eimeria sp. sebesar 31 ekor (31\%) dan infeksi tunggal sebesar $47 \%$ yang masing-masing sebesar, Trichomonas gallinae 18 ekor (18\%) dan Eimeria sp. 29 ekor (29\%). Prevalensi infeksi protozoa saluran cerna burung merpati pada sistem pemeliharaan ekstensif lebih besar (88\%) dari sistem pemeliharaan intensif (68\%).

Tabel 1. Hasil Pemeriksaan Infeksi Protozoa Saluran Cerna Burung Merpati di Surabaya

\begin{tabular}{lcccccc}
\hline \multirow{2}{*}{ Wilayah } & \multicolumn{2}{c}{ Sistem Pemeliharaan Ekstensif } & \multicolumn{2}{c}{ Sistem Pemeliharaan Intensif } \\
& T. gallinae & Eimeria sp. & Campuran & T. gallinae & Eimeria sp. & Campuran \\
\hline Surabaya Utara & $4 / 20(20 \%)$ & $5 / 20(25 \%)$ & $1 / 20(5 \%)$ & $1 / 20(5 \%)$ & $4 / 20(20 \%)$ & 0 \\
Surabaya Timur & $10 / 20(55 \%)$ & $7 / 20(35 \%)$ & $7 / 20(35 \%)$ & $2 / 20(10 \%)$ & $8 / 20(40 \%)$ & $1 / 20(5 \%)$ \\
Surabaya Selatan & $2 / 20(10 \%)$ & $4 / 20(20 \%)$ & $3 / 20(15 \%)$ & $\begin{array}{c}4 / 20 \\
(20 \%)\end{array}$ & 0 & $5 / 20(25 \%)$ \\
Surabaya Barat & $1 / 20(5 \%)$ & $2 / 20(10 \%)$ & $6 / 20(30 \%)$ & 0 & $1 / 20(5 \%)$ & $4 / 20(20 \%)$ \\
Surabaya Pusat & $2 / 20(10 \%)$ & $3 / 20(15 \%)$ & $1 / 20(5 \%)$ & 0 & $3 / 20(15 \%)$ & $3 / 20(15 \%)$ \\
TOTAL & $\mathbf{1 8 / 1 0 0 ( 1 8 \% )}$ & $31 / 100(31 \%)$ & $18 / 100(18 \%$ & $\begin{array}{c}7 / 100 \\
(7 \%)\end{array}$ & $\begin{array}{c}16 / 100 \\
(16 \%)\end{array}$ & \begin{tabular}{c}
$13 / 100(13 \%)$ \\
\hline
\end{tabular}
\end{tabular}


Hasil analisis menggunakan chi square test antara sistem pemeliharaan dan prevalensi infeksi protozoa saluran cerna burung merpati menunjukkan perbedaan nyata dengan nilai $\mathrm{p}=0,030 \quad(\mathrm{p}<0,050)$. Hasil tersebut menjelaskan bahwa sistem pemeliharaan pada burung merpati mempengaruhi besar prevalensi infeksi protozoa saluran cerna di Surabaya. Tingginya prevalensi pada sistem pemeliharaan ekstensif burung merpati di Surabaya disebabkan oleh cemaran yang mungkin dibawa burung merpati yang dibiarkan bebas keluar masuk kandang. Hal lain yang memicu tingginya infeksi yaitu segi sanitasi yang kurang memadai antara lain kebersihan kandang yang kurang terawat, pemberian jenis pakan yang apa adanya (sisa makanan pemelihara), dan juga kesehatan burung merpati yang kurang diperhatikan. Sedangkan pada sistem pemeliharaan ekstensif lebih mementingkan kesehatan burung merpati dengan sanitasi yang dijaga dengan baik, kebersihan kandang yang rutin, dan adanya kandang karantina bagi burung merpati yang telah memiliki gejala klinis suatu penyakit.

Analisis chi square test antara sistem pemeliharaan terhadap infeksi protozoa jenis Trichomonas gallinae menunjukkan bahwa infeksi protozoa tersebut bernilai signifikan atau berbeda nyata dengan nilai $\mathrm{p}=0,028 \quad(\mathrm{P}<0,05)$. Prevalensi infeksi mencapai $49 \%$ atau sejumlah 49 ekor positif pada 100 ekor merpati di Surabaya yang telah diperiksa. Pemeriksaan swab kerongkongan dengan metode natif terdeteksi adanya pergerakan atau moltilitas flagella Trichomonas gallinae yang kemudian melalui pewarnaan menggunakan Giemsa meninggalkan warna biru hingga ungu. Hasil tersebut didukung dengan hasil laporan penelitian yang dilakukan oleh Bunbury et al (2007) dan Saleem et al (2008) dengan prevalensi infeksi Trichomonas gallinae sebesar $44,3 \%$ dan $43 \%$ di Afrika Timur dan Pakistan.

Perbedaan tingkat infeksi pada setiap penelitian tersebut disebabkan karena perbedaan manajemen dengan tingkat sanitasi dan kebersihan kandang yang berbeda. Pernyataan tersebut sesuai dengan uraian dari Saleem et al (2008) yang menegaskan bahwa perbedaan tingkat in- feksi disebabkan beberapa faktor antara lain kondisi iklim, perbedaan geografis, perbedaan musim, imunitas individu merpati, kualitas pakan, perbedaan sanitasi kandang, sistem pemeliharaan yang berbeda, dan lainnya.

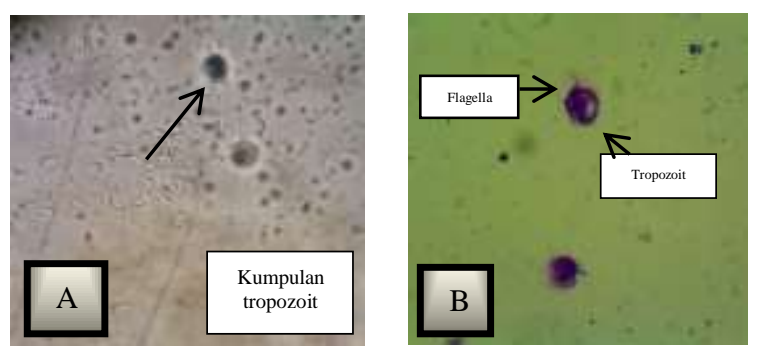

Gambar 1. Tropozoit Trichomonas gallinae. (A) Pemeriksaan swab Natif (40ox) Tanpa Pewarnaan. (B) Pemeriksaan swab Menggunakan Pewarnaan Giemsa(1.00ox)

Analisis chi square test selanjutnya antara sistem pemeliharaan dengan prevalensi infeksi protozoa Eimeria sp. menunjukkan hasil yang tidak berbeda nyata dengan nilai $\mathrm{p}=0,412$ $(\mathrm{P}>0,05)$. Prevalensi infeksi Eimeria sp. pada saluran pencernaan burung merpati tidak ditentukan oleh sistem pemeliharaannya, sehingga baik sistem pemeliharaan ekstensif maupun intensif memiliki peluang yang sama besar terhadap infeksi Eimeria sp. Tingkat infeksi oleh Eimeria sp. ini menunjukkan persentase tertinggi yaitu sebesar $61 \%$. Penemuan tersebut didukung dengan hasil penelitian dari Gú́L et al. (2009) dengan hasil penelitan $67,58 \%$ sampel positif terdeteksi Eimeria sp. Protozoa tersebut terdeteksi dari morfologi yang khas pada stadium ookista.

Tingkatan prevalensi tertinggi terjadi pada burung merpati yang dibiarkan terbang bebas oleh pemiliknya, atau dengan sistem pemeliharaan ekstensif. Penjelasan tersebut sesuai dengan penjelasan yang dijabarkan oleh Aleksandra and Pilarzyk (2014) bahwa prevalensi yang lebih besar ditunjukkan pada induvidu merpati yang diikutkkan perlombaan dibandingkan dengan individu merpati yang tersisa dalam kandang. 

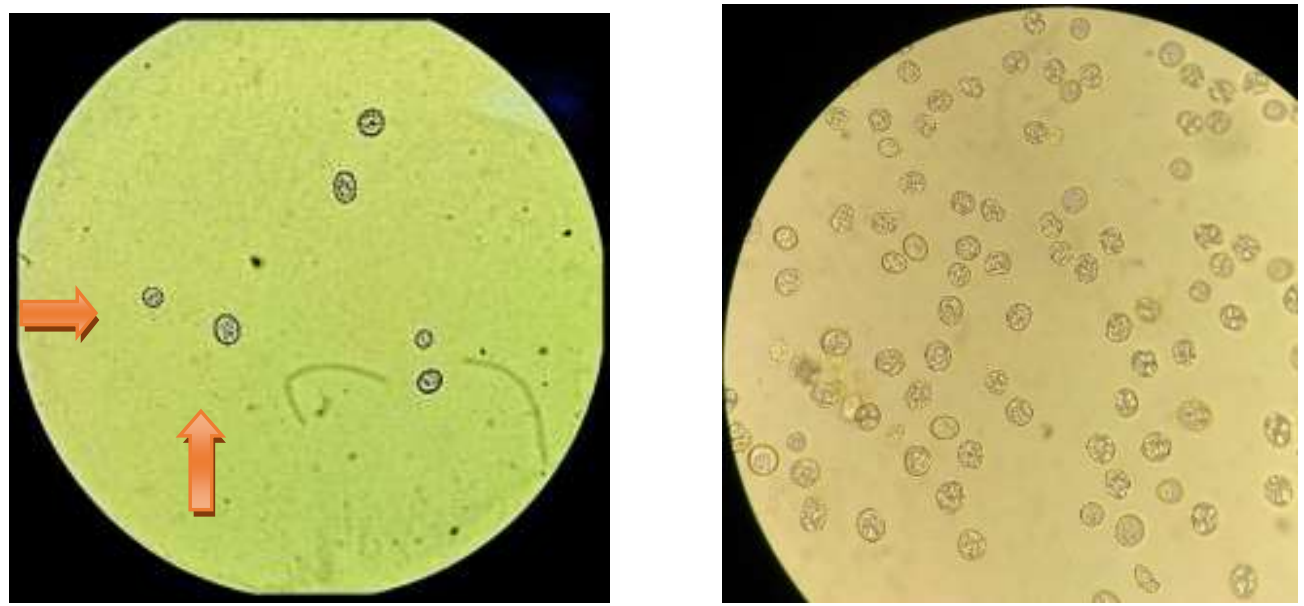

Gambar 2. Berbagai Bentuk dan Ukuran Ookista Eimeria sp. dengan Perbesaran 40ox.

\section{Kesimpulan}

Prevalensi protozoa saluran cerna burung merpati di wilayah Surabaya adalah sebesar $78 \%$. Protozoa yang menginfeksi saluran cerna burung merpati di Surabaya adalah Trichomonas gallinae(49\%) dan genus Eimeria sp. (61\%). Besar prevalensi protozoa saluran cerna burung merpati pada sistem pemeliharaan ekstensif memiliki persentase lebih tinggi sebesar $44 \%$, dibandingkan dengan sistem pemeliharaan intensif yang memiliki persentase sebesar $34 \%$.

\section{Daftar Pustaka}

Adejinmi, J.O. and M. Oke. 2011. Gastrointestinal parasites of Domestic Ducks (Anas platyrhynchos) in Ibadan South western Nigeria. Asian J. Poult Sci. 5 (1): 46- 50.

Bunbury, N., C.G. Jones, A.G. Greenwood, and D.J. Bell. 2007. Trichomonas gallinae in Muaritian Columbids: Implication for an Endangered Endemic. East Africa. Journal of Wildlife Disease. 43(3): 399-407.

Dove, A., O.Z. Rojs, A.V. Rataj, Hibrovsek, V.U. Krapez and M. Dobei. 2004. Health Status of Freeliving Pigeons (Columba livia domestica) in the City of Ljubljana. Acta Vet. Hung 52 (2): $219-226$.

Dranzoa, C., M. Ocaido and P. Katete. 1999. The Ecto-gastro-intestinal and Haemo Parasites of live pigeons (Columba livia) in Kampala, Uganda. Avian Pathology. 28: 119-124.
GứL, A.; ÒZdal, N.; Deĝer, S. and Denizhan, V. 2009. Prevalence of coccidia and helminth species in domestic pigeons (Columba livia domestica) in Van. Yó́zóncố yil úniversitesi Veteriner Fakúltesi. Dergisi., 2o(2): 45 - 48.

Hamid, A., E.J Saleh dan S. Fathan. 2015. Pola Tingkah Laku Makan Burung Merpati (Columba Livia) Jantan yang Dipelihara secara Intensif. Gorontalo. Universitas Negeri Gorontalo. Hal: 1-12

Natadisastra, D., R. Agus. 2009. Parasitologi Kedokteran. Ditinjau dari Organ Tubung yang Diserang. Penerbit Buku Kedokteran EGC. Jakarta. Hal: 383-395.

Prasetyo, R.H. 2005. Pengantar Praktikum Protozoologi Kedokteran. Airlangga University Press. Surabaya. Edisi 2. 91-93.

Saleem, M.H., M.S. Khan, A.S. Chaundry, and H.A Samad. 2008. Prevalence of Trichpmoniasis in Domestic and Wild Pigeons and Its Effects on Hematological Parameters. Pakistan. Vet.J., 28(2):89-91.

Samour, J. H., T. A. Bailey and J. E. Cooper, 1995. Trichomoniasis in birds of prey (order Folconiforms) in Bahrain. Vet. Rec., 136: 358362.

Saumier, M.D., M.E. Rau and D.M. Bird. 1991. Behavioural changes in breeding American Kestrels infected with Trichinellapseudospiralis. Pages 290-313 in Bird-parasite interactions(eds. J.E. Loye and M. Zuk.), pp. 290-313. Oxford University Press. Oxford. 
Sucitrayani, P., T.E. Oka, I.B.M. Dwinata. 2014. Prevalensi Infeksi Protozoa Saluran Pencernaan pada Kucing Lokal (Felis catus) di Denpasar. Buletin Veteriner Udayana. 6(2) hal. 153-159.
Suwanti, L.T., N.D.R Lastuti, E. Suprihati, Mufasirin. 2012. Buku Ajar Protozoologi Veteriner. Universitas Airlangga. Surabaya hal: $21-4$ 